\title{
Erratum to: International comparison of the determination of cadmium and lead in herb: the Comité Consultatif pour la Quantité de Matière (CCQM) pilot study CCQM-P97
}

\author{
Y. C. Wong - D. W. M. Sin - Y. C. Yip $\cdot$ L. Valiente $\cdot$ A. Toervenyi $\cdot$ \\ J. Wang - G. Labarraque $\cdot$ P. Gupta $\cdot$ D. Soni $\cdot$ Surmadi $\cdot$ E. Hwang $\cdot$ \\ C. Yafa $\cdot$ O. Cankur $\cdot$ E. Uysal $\cdot$ G. Turk $\cdot$ R. Huertas $\cdot$ K. E. Murphy
}

Published online: 22 June 2010

(c) Springer-Verlag 2010

\section{Erratum to: Accred Qual Assur (2009) 14:151-158 \\ DOI 10.1007/s00769-009-0491-1}

Unfortunately, the co-author K. E. Murphy's name was omitted in the original version of the article. Her name and affiliation are shown here.

K. E. Murphy

National Institute of Standards and Technology, Gaithersburg, USA

The online version of the original article can be found under doi:10.1007/s00769-009-0491-1.

Y. C. Wong $(\bowtie)$. D. W. M. Sin · Y. C. Yip

Government Laboratory, Homantin, Hong Kong

e-mail: ycwong@govtlab.gov.hk

\section{Valiente}

Instituto Nacional de Tecnologia Industrial,

Buenos Aires, Argentina

A. Toervenyi

International Atomic Energy Agency, IAEA, Vienna, Austria

J. Wang

National Institute of Metrology, Beijing, China

\section{G. Labarraque}

Laboratoire National de Métrologie et d'essais, Paris, France

P. Gupta · D. Soni

National Physical Laboratory India, New Delhi, India

Surmadi

Indonesian Institute of Sciences, Bandung, Indonesia

\author{
E. Hwang \\ Korea Research Institute of Standards and Sciences, \\ Daejeon, Republic of Korea \\ C. Yafa \\ National Institute of Metrology Thailand, Pathumthani, Thailand \\ O. Cankur · E. Uysal \\ Tubitak National Metrology Institute, Gebze Kocaeli, Turkey \\ G. Turk · K. E. Murphy \\ National Institute of Standards and Technology, \\ Gaithersburg, USA \\ R. Huertas \\ Laboratorio Tecnologico de Uruguay, Montevideo, Uruguay
}

